\title{
The effects of funding on student performance: Findings from PISA 2018
}

\author{
Gabriella Szekeres (Váncza) ${ }^{1 \mathrm{a}}$, Alina Căldăraru ${ }^{\mathrm{a}}$ \\ and Mihai Păunicăa
}

${ }^{a}$ Bucharest University of Economic Studies

\begin{abstract}
Research Question: Is there a link between the investment in human capital, measured by the average gross salary in the pre-university education system and the student-teacher ratio together with the results obtained by students in tests?

Motivation: In any society, the work done by man to obtain results is always present. Human capital in the economic and accounting context cannot be dissociated from its cost, and in the public system, it acquires an even greater influence. The role of human capital and implicitly its cost in the public expenditure system represents the largest part, and its significance is accentuated in education.
\end{abstract}

Idea: The authors of this paper tried to see if investing in human capital has positive consequences on the outcome of the pre-university education system.

Data: Research data were collected from the OECD (Organization for Economic Cooperation and Development) website

Tools: The research was performed by quantitative methods using the least squares regression equation. The hypotheses tested by the authors were the existence of a relevant positive or negative correlation between the indicators presented.

Findings: Following the analysis, found that there was a positive correlation between the salary level indicators and the average score obtained in tests, and a negative correlation between the number of students per teacher and test results.

Contribution: This paper contributes to research in the field on the effects of decisions regarding funding and pay policy for pre-university education using the results obtained by students in standardized tests. Therefore, this research is part of a larger research project that shows that the level of funding is correlated with the results of students measured by tests in pre-university education.

${ }^{1}$ Corresponding author: Gabriella Szekeres (Váncza), Bucharest University of Economic Studies, Tel. (+40) 742261709, email address: vanczagabriella@gmail.com 
Keywords: salary costs in the education system, PISA tests, number of students per teacher, financing in education.

JEL codes: H52, P44, P43, H61, I22, M48, H75

\section{Introduction}

The public sector composed of those public organizations that provide public services to society has traditionally been owned and controlled by the state (Broadbent \& Guthrie,1992). Public pre-university education is part of the public sector. The functioning of the public sector requires a very accurate forecast of revenues and expenditures. The role accounting in public institutions is to provide a true and accurate picture of the state of affairs regarding the assets, receivables and liabilities, income and expenses of entities. This role is fulfilled with the help of several specific instruments such as: revenue and expenditure budget, quarterly and annual reports, execution accounts and others. In any education system, a basic principle must be equal opportunities, meaning that every child has to the opportunity to access all types of educational offer at all levels. "...equality of educational opportunity exists when the community provides the same resources, the same facilities, for all children" (Coleman, 1969: 347). From the point of view of equal opportunities, the level of funding in education is essential. The level of funding is a component, part of the budgeting process, with the revenue and expenditure budget being a basic tool of budgetary accounting.

The central role of budgeting in public organizations is that a nation's revenues and expenditures are highlighted, allocated, and managed through revenue and expenditure budgets (OECD, 2014). The revenue and expenditure budget plays different roles in the economy. The roles of the budget include the role of allocation, the role of management, and the role of external responsibility (Schick, 2003). Within the allocation function, the budget establishes the limits of budgetary expenditures broken down by budgetary roles and/or organizations (Anessi-Pessina et al., 2016). According to the managerial role, it draws the limits between which the management carries out its activity regarding the material resources that can be engaged in order to maximize the results. According to the requirements of transparency, among the instruments for assuming institutional responsibility is the budget document of revenues and expenditures, in addition to the reports and execution accounts providing the necessary information to internal and external auditors regarding the expenditure of public money.

In the education system, with the introduction of accrual-based accounting, there was a need to look at the budgeting process from a different perspective. The idea of New Public Management promoting the principles of market economy in the budget sector introduced new paradigms such as result-oriented behaviour, performance 
quantification or emphasis on value for money, encouraging the emergence of new management methods and the need to empower service providers (Bracci et al., 2015). In the other hand, there are researchers who say that new functions can be added to the budget document to measure performance, but there is almost never a link between resource allocation and actual performance (Kelly, 2003). However, the budgeting process and implicitly the budget document is able to generate restructuring in public sector systems. Thus, the budgets were the generators of transformations in the education system in Great Britain, creating centres of responsibility and adding a greater budgetary autonomy to the schools (Ezzamel et al., 2012). At the same time, the new economy, the knowledge economy or the information economy, brought new demands for education by the population (Achim, 2015)."The cost of an education has been qualified and quantified by contemplating the economical, societal, psychological and emotional costs of formal knowledge, or lack thereof'(Watlington et al., 2010, p.22).

Extensive research has been carried out on the method of financing in determining the financing of educational expenses. The best financing method is the one that covers the expenses, is predictable, objective and as simple as possible (Agyemang, 2010). The need-based formula funding aims to meet all these requirements by bringing a new approach to the existing one, based on historical costs and, in the meantime, enriching itself with principles such as efficiency, effectiveness and accountability (Agyemang, 2010). Salary expenses in an educational institution represent the largest part of the costs (Edwards, 1989), so the analysis of the effect of the salary level on the results is a much researched problem over time.

This study, according to the nature of the subject, is intended for researchers in the economic, financial and accounting fields, especially in the public institutions and aims to draw the attention of policy makers to give special importance to educational policies in making decisions on teacher salaries and average numbers of students on a teacher (student-teacher ratio) because based on this research, the two indicators have an important influence on the achievements of students in pre-university education. At the same time, this research can be beneficial to the managers of the pre-university educational institutions when they make decisions regarding the organization of the educational process or the monetary compensation of the employees. The approach of this research is a mathematical one based on quantitative research methods.

The article is further structured as follows: Chapter 2 presents studies and research in the literature, Chapter 3 describes tested hypothesis, Chapter 4 presents methodology and methods, Chapter 5 shows the results obtained, Chapter 6 presents discussions and Chapter 7 draws conclusions. 


\section{Literature review}

The level of teachers' salaries has been a vast area of study for many researchers. Landon and Baird 1971 believed that competition between schools would increase wage levels and raise the quality of education. Since 1980, Chang made an estimate of a cross-sectional showing the cost of education. Based on the Cobb-Douglas equation, this index looks for the relationship between prices and the quality of inputs used in education, expressed through labour market variables and local spending on education. The conclusion of the research was that there was a close relationship between the labour market of teachers and the unit cost of education in the state of Virginia (USA) (Chang, 1980). Childs and Shakeshaft (1986) performed a meta-analysis on the relationship between the costs of education and student achievement and found that there was a very small positive correlation between the two variables with the values of $\mathrm{r} 2$ ( $\mathrm{r}$ square) between $3 \%$ and $15 \%$, with a better relationship between direct education expenditures such as salaries and the cost of training materials.

Edwards (1989) analysed the large differences in wage incomes between different countries and concluded that a comparison of teachers' salaries with national per capita income does not reflect which country pays "too much" for teachers. In 1997, Figlio showed that there was a close and strong correlation between teachers' salaries and the quality of services provided in local professional labour markets. Lin (2010), examining 500 schools in Pennsylvania, found that higher salary teachers induce an increased quality of teaching and increase the output. The European Commission, conducting a survey of the basic salaries of teachers in the 2016/2017 school year, found that the real salaries of beginner teachers indexed to inflation were lower in nine European countries than in 2009/10, in the years following the financial crisis. Differences among countries not only concern the basic wages but also the number of years of service required to achieve maximum, which varies greatly from country to country and can go from 6 to 42 years (European Comision, 2018). The study shows that remuneration is a key element in the attractiveness of the profession of teachers (European Comision, 2018).

In the US, according to the 2000 census, the average earnings of teachers were lower than the average earnings of other categories of employees with higher education (Taylor, 2008). It raises the question that if wage affects student performance, then what is the effect of large differences between the level of salaries between countries. Leigh (2012: 41) states that "Recent studies have provided substantial evidence in favor of two propositions: teacher quality is an important determinant of student achievement; and teacher aptitude has declined substantially over the past generation". The study investigates whether teacher salary affected the quality of services or whether it was the quality that affected the salaries of teachers? Others looked for answers to the phenomenon of declining quality of services provided by 
teachers and thus the decline in student performance in the US between 1980 and 2002 and found that wage changes in the sense of compression are to blame in a percentage of $25 \%-80 \%$ other factors for this decline making a contribution of 19\% (Hoxby \& Leigh, 2004). The decline in service quality was produced although spending per student in the US since 1960 has increased by about $6 \%$ per decade faster than GDP (Wilson et al., 2004). As student outcomes also depend on many other factors such as the human psychological factor, the number of students in relation to the number of teachers, or the continuity of the teacher-student relationship, others concluded that general salary increases for teachers would be costly and inefficient. "The best way to improve the quality of instruction would be to lower barriers to be- coming a teacher, such as certification, and to link compensation and career advancement more closely with teachers' ability to raise student performance" (Hanushek \& Rivkin, 2007: 69). At the same time, in the neighboring regions, teachers' salaries tend to equalize and stand at a certain level, which depends on the average per capita income in that region and the adjacent ones (Kirby et al., 1993).

Wage differences between schools affect the quality of teaching services, generating large differences between "rich and poor" schools, so a monetary compensation for teachers who teach in poor schools could solve this problem (Goldhaber et al., 2010). Cash compensation for teachers who teach in schools in poor regions or in schools with low test scores has been made in North Carolina (USA) to reduce teacher migration, a factor that negatively influences student performance by hindering continuity in the teaching process. The effect of this measure was to reduce the migration of teachers by $17 \%$, with more experienced teachers responding to a higher percentage of this measure (Clotfelter et al., 2008). Others have found that it is necessary to increase the wages of $7.3 \%$ to reduce the teacher migration rate by $22 \%$ (Feng, 2020). Imazeki (2005) showed that in England, the migration of teachers due to attrition could be reduced by a salary increase of at least 10-15\% compared to the level existing. While Coleman report said that the influence of the school is less than family influence, Rivkin et al. (2005) demonstrated the importance of school quality influence on the results in a way that excludes the possibility that the observed differences could be caused by family factors. Leigh (2012) studied the effect of increasing teachers' salaries on the performance of students participating in teacher training schools. "A 1 percent rise in the salary of a starting teacher boosts the average aptitude of students entering teacher education courses by 0.6 percentile ranks, with the effect being strongest for those at the median" (Leigh, 2012: 41).

Cebula et al. (2015) investigated whether the results of students from different ethnic groups depend on human capital measured by teachers' income and their quality. Taking into account the results of 172 schools in the Los Angeles region, they concluded that the variation of any of the two variables between the minimum and maximum level (teacher income and teacher quality) leads to an increase in academic performance of three to six percentage points. Britton and Propper (2016) researched 
the effect of teachers' income levels on school productivity, taking into account the results of national examinations at the entrance and exit of the education system at the level of compulsory education as an added value. They found that, on average, a $10 \%$ increase in teachers' salaries in the local labour market leads to an average increase of $2 \%$ in the scores obtained at the end of compulsory schooling in England (Britton \& Propper, 2016). More recently, Greaves and Sibieta (2019) have researched that if salaries are increased at the expense of other, expenses that are not directly related to training, implicitly decrease teacher absences, as well as their effect on student outcomes. The combined total effect on students' higher teacher salaries, reduced teacher absences, and reduced non-instructional spending is estimated to be very close to zero (Greaves \& Sibieta, 2019). Akiba et al. (2012) conducted research on the effect of wages on student performance as measured by the average mathematics score from the 2006 PISA tests of OECD countries (The Organization for Economic Co-operation and Development) and found that the average salaries of more experienced teachers have a greater influence on the results than those without experience.

\section{Tested hypotheses}

Some researchers opinate that there is no relationship or only a negligible one between the investments in the education system achievements of the students (Hong \& Zimmer, 2016; Martorell et al., 2016). According to Hanushek (1997) these results may be partly due to some schools not increasing resources efficiently. However, in the specialized literature, we found other articles in which a rather strong correlation was found between the financing components of the educational system. These are the staff income, the number of students per teacher and the performances of the students (Akiba et al., 2012; Belmonte et al., 2020; Holmlund et al., 2010; Hyman, 2017).

Empirical studies that examine the relationship between teachers' salaries and students' performance are few and far between, and they give varying results. Most of them found a strong and positive relationship between the salary level and the students' test results (Britton \& Propper, 2016; Cebula et al., 2015; Kingdon \& Teal, 2007; Leigh, 2012; Southwick \& Gill, 1997), and others showed that it cannot be said that there is a strong and indisputable correlation between these variables (Hanushek \& Rivkin, 2007; Ladd, 2007).

Based on the arguments shown above, the fundamental question of this research is: Q1: To what extent do teachers' salaries and the number of students per teacher influence students' academic performance?

The following hypotheses were derived from the literature to be tested in response to this question: 
H1. The variation of salaries is in positive correlation with the average scores obtained in the tests of mathematics, science and reading;

H2. The variation in the number of students per teacher is in a negative correlation with the average scores of the PISA tests.

\section{Methodology and methods}

\subsection{Strategy and context of the research}

Given: (1) the limitations of researching psychological and social factors that determine performance of the students and (2) the importance of identifying whether the level of funding effects the test scores or leads to correct decisions about investments in education, the authors were limited to the analysis of financial factors that affect student performance. In the process of determining the funding formula in the education system based on the cost per student in terms of human capital expenditures, the most important indicators are:

- the level of average gross salaries applied according to the salary scales in the education system

- the level of the number of students per teacher

These two indicators have a particular influence on the average cost per student and the question is whether the variations of these two indicators significantly influence school performance given that maintaining a low level of salaries at the same time with a high number of students per teacher would be the most economically justified. At the same time, the fact that not all researchers agree that the salary level in education is correlated with academic performance, the authors wanted to analyse whether these two indicators influence the students' results obtained in the tests. In order to complete objectives of the research, it was necessary to collect quantitative data for all the cases.

Data were collected from OECD websites about the level of salaries and the number of students per teacher, as well as the average score of PISA tests obtained by students from the participating countries. To measure the results, as a dependent variable, the authors decided to use a standardized test, namely, the 2018 PISA (Program for International Student Assessment - PISA) test conducted by the OECD (Organization for Economic Co-operation and Development), a test that measures skills reading, math and science of 15-year-old students and their ability to use these skills in real life. 15-year-old students in most countries at the end of compulsory education are tested online or on paper in three basic areas. The tests are standardized precisely so that the results are comparable and measure most of the knowledge, skills, and attitudes acquired in compulsory education in institutionalized educational institutions. PISA assessments do not only check whether students 
nearing the end of compulsory education can replicate what they have learned, they also examine how well students can extrapolate from what they have learned and apply their knowledge in unfamiliar environments, both in school and out of it (OECD, 2018).

\subsection{Research data}

As we have seen before, research in the field shows different results in terms of the link between funding and student outcomes. These inconsistent results may be due to the fact that performance of the students was not measured with standardized, uniform tests for all schools, or the tests measured the subject taught in the curriculum differed from case to case. In this paper it was intended to analyse the effect of the variation of teachers' salaries and the number of students per teacher on students' test scores. The data on the OECD page show the average gross level of salaries differentiated by education levels, starting from the level of early education and ending with the level of secondary education at the beginning of the career, after 15 years of experience and at the highest level (OECD, 2020). The rate of the number of students per teacher expresses the ratio between the number of full-time equivalent students enrolled at one level of education divided by the total number of full-time equivalent teachers at the same level (OECD, 2020). The data collected from the official OECD website is presented in Tables 1. 2. and 3. The salary data for 2017 from the lower secondary level can be found in Table1.

Table 1. The level of salaries and their change in 2017

\begin{tabular}{lrrrrr}
\hline LOCATION & $\begin{array}{c}\text { Starting } \\
\text { salary }\end{array}$ & $\begin{array}{c}\text { 15 year } \\
\text { salary }\end{array}$ & $\begin{array}{c}\text { Increase } \\
\text { 15 years - } \\
\text { start (\%) }\end{array}$ & Top salary & $\begin{array}{c}\text { Increase } \\
\text { top-15 } \\
\text { years (\%) }\end{array}$ \\
\hline Brasilia & 13971 & $:$ & $:$ & $:$ & $:$ \\
Latvia & 14252 & $:$ & $:$ & $:$ & $:$ \\
Slovakia & 14267 & 20057 & $41.00 \%$ & 21625 & $8.00 \%$ \\
Poland & 15600 & 25553 & $64.00 \%$ & 26636 & $4.00 \%$ \\
Hungary & 15752 & 20629 & $31.00 \%$ & 27031 & $31.00 \%$ \\
Czechia & 18953 & 21049 & $11.00 \%$ & 24901 & $18.00 \%$ \\
Greece & 19374 & 25998 & $34.00 \%$ & 37699 & $45.00 \%$ \\
Lithuania & 19385 & 19696 & $2.00 \%$ & 19882 & $1.00 \%$ \\
Estonia & 19529 & $:$ & & & $:$ \\
Israel & 20159 & 33442 & $66.00 \%$ & 53650 & $60.00 \%$ \\
Chile & 23429 & 34231 & $46.00 \%$ & 43760 & $28.00 \%$ \\
Costa Rica & 24893 & 31580 & $27.00 \%$ & 38266 & $21.00 \%$ \\
Mexico & 25401 & 40595 & $60.00 \%$ & 51139 & $26.00 \%$ \\
Turkey & 26219 & 28835 & $10.00 \%$ & 33288 & $15.00 \%$ \\
Slovenia & 26823 & 40351 & $50.00 \%$ & 48166 & $19.00 \%$ \\
Korea & 30455 & 53465 & $76.00 \%$ & 84902 & $59.00 \%$ \\
Japan & 30631 & 51593 & $68.00 \%$ & 63969 & $24.00 \%$ \\
Italy & 30739 & 37530 & $22.00 \%$ & 46030 & $23.00 \%$ \\
& & & & &
\end{tabular}


Accounting and Management Information Systems

\begin{tabular}{lrrrrr}
\hline LOCATION & $\begin{array}{c}\text { Starting } \\
\text { salary }\end{array}$ & $\begin{array}{c}\text { 15 year } \\
\text { salary }\end{array}$ & $\begin{array}{c}\text { Increase } \\
\text { 15 years - } \\
\text { start (\%) }\end{array}$ & Top salary & $\begin{array}{r}\text { Increase } \\
\text { top-15 } \\
\text { years (\%) }\end{array}$ \\
\hline New Zeeland & 30746 & 46963 & $53.00 \%$ & 46963 & $0.00 \%$ \\
France & 31003 & 37450 & $21.00 \%$ & 54010 & $44.00 \%$ \\
Portugal & 32887 & 42489 & $29.00 \%$ & 65417 & $54.00 \%$ \\
Ireland & 33962 & 60053 & $77.00 \%$ & 69306 & $15.00 \%$ \\
Iceland & 35756 & 39477 & $10.00 \%$ & 39477 & $0.00 \%$ \\
Finland & 36081 & 44271 & $23.00 \%$ & 46927 & $6.00 \%$ \\
Sweden & 37566 & 43827 & $17.00 \%$ & 50964 & $16.00 \%$ \\
Canada & 39222 & 65474 & $67.00 \%$ & 65474 & $0.00 \%$ \\
Norway & 39585 & 47687 & $20.00 \%$ & 51209 & $7.00 \%$ \\
United States & 39707 & 63046 & $59.00 \%$ & 68052 & $8.00 \%$ \\
Austria & 40411 & 52538 & $30.00 \%$ & 78495 & $49.00 \%$ \\
Netherland & 41309 & 72778 & $76.00 \%$ & 84469 & $16.00 \%$ \\
Australia & 41800 & 59568 & $43.00 \%$ & 59568 & $0.00 \%$ \\
Spain & 43565 & 50257 & $15.00 \%$ & 61543 & $22.00 \%$ \\
Denmark & 45134 & 52183 & $16.00 \%$ & 52183 & $0.00 \%$ \\
Switzerland & 63308 & $:$ & $:$ & 96997 & $:$ \\
Germany & 63555 & 76838 & $21.00 \%$ & 83451 & $9.00 \%$ \\
Luxembourg & 79551 & 109734 & $38.00 \%$ & 138279 & $26.00 \%$ \\
Colombia & $:$ & $:$ & & & $:$ \\
\hline Special value: not available & & & & & $:$ \\
& & $($ Source: & $:$ & &
\end{tabular}

(Source: OECD)

As can be seen in Table 1. the highest level of salaries for beginners in the 2017 appears to be in Luxembourg with $45.8 \%$ higher than the average of the countries studied. At the same time, it can be observed that in some countries, after 15 years of experience, there was a substantial increase in salaries of over 50\%: Slovenia, New Zeeland, Mexico, United States, Israel, Poland, Japan, Canada, Ireland, Korea, Netherland and in others in 15 years the maximum level of wages is reached, in countries like: Iceland, Denmark, New Zeeland, Canada. The lowest level of beginner salaries can be seen in the following countries: Brasilia, Latvia, Slovakia, Poland, Hungary. This aspect of the salary level is important because a low salary of teachers leads to their dissatisfaction and burnout in most cases (Akiba et al., 2012). The salary data for 2018 from the lower secondary level can be found in Table 2 .

Table 2. The level of salaries and their change in 2018

\begin{tabular}{lrrrrr}
\hline LOCATION & $\begin{array}{c}\text { Starting } \\
\text { salary }\end{array}$ & $\begin{array}{c}\text { 15 year } \\
\text { salary }\end{array}$ & $\begin{array}{c}\text { Increase } \\
\text { 15 years - } \\
\text { start (\%) }\end{array}$ & $\begin{array}{c}\text { Top } \\
\text { salary }\end{array}$ & $\begin{array}{c}\text { Increase } \\
\text { top-15 } \\
\text { years (\%) }\end{array}$ \\
\hline Latvia & 14494 & $:$ & $:$ & $:$ & $:$ \\
Brasilia & 14775 & $:$ & $:$ & $:$ & $:$ \\
Slovakia & 15339 & 21553 & $41.00 \%$ & 23242 & $8.00 \%$ \\
Poland & 16140 & 26428 & $64.00 \%$ & 27549 & $4.00 \%$
\end{tabular}


The effects of funding on student performance: Findings from PISA 2018

\begin{tabular}{|c|c|c|c|c|c|}
\hline LOCATION & $\begin{array}{c}\text { Starting } \\
\text { salary }\end{array}$ & $\begin{array}{c}15 \text { year } \\
\text { salary }\end{array}$ & $\begin{array}{l}\text { Increase } \\
15 \text { years - } \\
\text { start }(\%)\end{array}$ & $\begin{array}{c}\text { Top } \\
\text { salary }\end{array}$ & $\begin{array}{c}\text { Increase } \\
\text { top-15 } \\
\text { years }(\%)\end{array}$ \\
\hline Hungary & 16161 & 21090 & $31.00 \%$ & 27635 & $31.00 \%$ \\
\hline Colombia & 19624 & 35788 & $82.00 \%$ & 41156 & $15.00 \%$ \\
\hline Greece & 19825 & 26198 & $32.00 \%$ & 38804 & $48.00 \%$ \\
\hline Lithuania & 20255 & 21084 & $4.00 \%$ & 21721 & $3.00 \%$ \\
\hline Israel & 21389 & 34860 & $63.00 \%$ & 56000 & $61.00 \%$ \\
\hline Czechia & 21854 & 24359 & $11.00 \%$ & 28851 & $18.00 \%$ \\
\hline Estonia & 22178 & : & $:$ & : & : \\
\hline Chile & 23747 & 34577 & $46.00 \%$ & 44107 & $28.00 \%$ \\
\hline Costa Rica & 25251 & 31994 & $27.00 \%$ & 38736 & $21.00 \%$ \\
\hline Turkey & 25955 & 28545 & $10.00 \%$ & 32953 & $15.00 \%$ \\
\hline Mexico & 26560 & 42316 & $59.00 \%$ & 53262 & $26.00 \%$ \\
\hline Slovenia & 28031 & 42111 & $50.00 \%$ & 50539 & $20.00 \%$ \\
\hline Japan & 30560 & 51339 & $68.00 \%$ & 63562 & $24.00 \%$ \\
\hline New Zeeland & 31392 & 47950 & $53.00 \%$ & 47950 & $0.00 \%$ \\
\hline France & 32492 & 39320 & $21.00 \%$ & 56283 & $43.00 \%$ \\
\hline Korea & 32548 & 57242 & $76.00 \%$ & 90973 & $59.00 \%$ \\
\hline Italy & 32725 & 39840 & $22.00 \%$ & 48833 & $23.00 \%$ \\
\hline Portugal & 33516 & 43279 & $29.00 \%$ & 72369 & $67.00 \%$ \\
\hline Ireland & 36553 & 62135 & $70.00 \%$ & 71568 & $15.00 \%$ \\
\hline Finland & 36629 & 45555 & $24.00 \%$ & 48288 & $6.00 \%$ \\
\hline Iceland & 38336 & 42368 & $11.00 \%$ & 42368 & $0.00 \%$ \\
\hline Norway & 38559 & 47387 & $23.00 \%$ & 50883 & $7.00 \%$ \\
\hline Canada & 39937 & 67301 & $69.00 \%$ & 67301 & $0.00 \%$ \\
\hline Sweden & 40348 & 47323 & $17.00 \%$ & 53885 & $14.00 \%$ \\
\hline United States & 40602 & 64467 & $59.00 \%$ & 69586 & $8.00 \%$ \\
\hline Austria & 42277 & 54406 & $29.00 \%$ & 81311 & $49.00 \%$ \\
\hline Netherland & 43132 & 76006 & $76.00 \%$ & 88464 & $16.00 \%$ \\
\hline Australia & 44247 & 63393 & $43.00 \%$ & 65560 & $3.00 \%$ \\
\hline Spain & 45509 & 52506 & $15.00 \%$ & 64473 & $23.00 \%$ \\
\hline Denmark & 49482 & 58349 & $18.00 \%$ & 58349 & $0.00 \%$ \\
\hline Switzerland & 65010 & : & $:$ & 99703 & : \\
\hline Germany & 67163 & 80993 & $21.00 \%$ & 88214 & $9.00 \%$ \\
\hline Luxembourg & 84320 & 116312 & $38.00 \%$ & 146568 & $26.00 \%$ \\
\hline
\end{tabular}

Vol. 20, No. 4 
After analysing Table 2, it can be observed that Luxembourg has the highest salary for beginners, just like in 2017 with 52.2\% more than the average \$33430. Akiba et al (2012) found the same result in 2005, 2006. On average, between the beginner salary and the salary after 15 years of experience, there is an increase of $40 \%$ and between the salary after 15 years of experience and the top salary, an increase of $23 \%$ in both years. The average salaries increased in 2018 compared to 2017 by $3 \%$ for the salaries of beginners and by $4 \%-4 \%$ for salaries for 15 years of experience and at the top salaries.

As we have shown, funding per student is closely related to the number of students in a study group. So, the authors considered that this variable may affect student performance. The data regarding the rate of students per teacher was downloaded from the OECD website and are presented in Table no. 3.

Table 3. Ratio of students per teaching staff

\begin{tabular}{lcccccc}
\hline LOCATION & Austria & Belgium & Brasilia & Switzerland & Chile & China \\
\hline Stud/teacher & 9.21 & 9.47 & 24.5 & 11.95 & 21.42 & 13.47 \\
\hline LOCATION & Colombia & $\begin{array}{c}\text { Costa } \\
\text { Rica }\end{array}$ & Czechia & Germany & Denmark & Spain \\
\hline Stud/teacher & 26.11 & 13.37 & 11.61 & 13.05 & 11.31 & 11.26 \\
\hline LOCATION & Estonia & Finland & France & Kingdom & Greece & Hungary \\
\hline Stud/teacher & 12.5 & 13.37 & 13 & 16.37 & 8.63 & 11.02 \\
\hline LOCATION & Indonesia & India & Ireland & Israel & Italy & Japan \\
\hline Stud/teacher & 14.88 & 29.03 & 6.58 & 10.34 & 10.96 & 12.5 \\
\hline LOCATION & Korea & Lithuania & Luxemb & Latvia & Mexico & Netherland \\
\hline Stud/teacher & 13.82 & 7.55 & 9.97 & 9.06 & 27.63 & 16.95 \\
\hline LOCATION & Norway & Zeeland & Poland & Portugal & Russia & Arabia \\
\hline Stud/teacher & 9.76 & 14.54 & 9.98 & 9.57 & 10.8 & 10.86 \\
\hline LOCATION & Slovakia & Slovenia & Sweden & Turkey & $\begin{array}{c}\text { Snited } \\
\text { States }\end{array}$ & $\begin{array}{c}\text { South } \\
\text { Africa }\end{array}$ \\
\hline Stud/teacher & 12.76 & 9.85 & 12.95 & 14.53 & 15.31 & 27.42 \\
\hline & & $($ Source: OECD) & &
\end{tabular}

The data shows that the highest level of student-teacher ratio is in the countries of India, Mexico, Chile, South Africa, Colombia, Brasilia with a rate over 20, and among the European countries the highest rates are found in: the Netherlands and UK. The lowest rates under 9 are found in countries like Greece, Ireland, Lithuania. Recently, many researchers used PISA tests to measure student performance in correlation with other independent variables. Giambona and Porcu (2018) used PISA results as a dependent variable in correlation with student characteristics, family context, cultural status, economic and social issues. Jerrim et al. (2019) analysed 
whether the results of English students in mathematics, reading and science measured using PISA tests depended on the teaching method used by the teachers. Karakolidis et al. (2016) used PISA tests to measure the math results of students in correlation with differences between schools in a linear regression.

Other researchers used PISA tests as a dependent variable in correlation with other independent variables such as school age (Suggate, 2009), inequalities between the level of education of the parents (Martins \& Veiga, 2010), material resources and school climate (Trinidad, 2020). Because the PISA tests do not investigate what students have learned during the curriculum, but the attitudes and skills they have really learned about life, so they are independent of different school curricula. Because of this and due to the fact that the tests are standardized, results are comparable across countries and since the test subjects are 15-years-old, authors believe that the test can be used as a measure of student achievement. The results of the latest PISA tests from 2018 were downloaded from the OECD website and are presented in table no.4.

Table 4. Average results of PISA scores by country

\begin{tabular}{lcccc}
\hline \multicolumn{1}{c}{ LOCATION } & Science & Math & Read & Av PISA Result \\
\hline Australia & 503 & 491 & 503 & 499 \\
Austria & 490 & 499 & 484 & 491 \\
Belgium & 499 & 508 & 493 & 500 \\
Brasilia & 404 & 384 & 413 & 400 \\
Canada & 518 & 512 & 520 & 517 \\
Switzerland & 495 & 515 & 484 & 498 \\
Chile & 444 & 417 & 452 & 438 \\
Colombia & 413 & 391 & 412 & 405 \\
Costa Rica & 416 & 402 & 426 & 415 \\
Czech Republic & 497 & 499 & 490 & 495 \\
Germany & 503 & 500 & 498 & 500 \\
Denmark & 493 & 509 & 501 & 501 \\
Spain & 483 & 481 & $:$ & 482 \\
Estonia & 530 & 523 & 523 & 525 \\
Finland & 522 & 507 & 520 & 516 \\
France & 493 & 495 & 493 & 494 \\
U Kingdom & 505 & 502 & 504 & 504 \\
Greece & 452 & 451 & 457 & 453 \\
Hungary & 481 & 481 & 476 & 479 \\
Indonesia & 396 & 379 & 371 & 382 \\
Ireland & 496 & 500 & 518 & 505 \\
Iceland & 475 & 495 & 474 & 481 \\
Israel & 462 & 463 & 470 & 465 \\
Italy & 468 & 487 & 476 & 477 \\
Japan & 529 & 527 & 504 & 520 \\
Korea & 519 & 526 & 514 & 520 \\
Lithuania & 482 & 481 & 476 & 480
\end{tabular}




\begin{tabular}{lcccc}
\hline \multicolumn{1}{c}{ LOCATION } & Science & Math & Read & Av PISA Result \\
\hline Luxembourg & 477 & 483 & 470 & 477 \\
Latvia & 487 & 496 & 479 & 487 \\
Mexico & 419 & 409 & 420 & 416 \\
Netherlands & 503 & 519 & 485 & 502 \\
Norway & 490 & 501 & 499 & 497 \\
New Zealand & 508 & 494 & 506 & 503 \\
Poland & 511 & 516 & 512 & 513 \\
Portugal & 492 & 492 & 492 & 492 \\
Russia & 478 & 488 & 479 & 482 \\
Slovakia & 464 & 486 & 458 & 469 \\
Slovenia & 507 & 509 & 495 & 504 \\
Sweden & 499 & 502 & 506 & 502 \\
Turkey & 468 & 454 & 466 & 463 \\
United States & 502 & 478 & 505 & 495 \\
\hline
\end{tabular}

Special value: not available

(Source: OECD)

\subsection{Research method}

We considered that the most appropriate method to estimate this influence is the multiple regression model, which can show whether there is a correlation between these indicators. Multiple regression tests the correlation between a dependent variable $\mathrm{y}$ and several independent variables $\mathrm{x}_{1} ; \mathrm{x}_{2} ; \ldots ; \mathrm{x}_{\mathrm{p}} \ldots$ The method used to estimate the parameters was the least squares method. The linear model of multiple regression can be expressed with Equation 1 (Andrei et al., 2018)

$y_{j}=a_{1}+a_{1} x_{1 j}+\ldots+a_{p} x_{p j}+\varepsilon_{j} \quad \mathrm{j}=1, \mathrm{n}$

Where: $\mathrm{y}_{\mathrm{j}}$ - dependent variable

$$
\begin{aligned}
& \mathrm{x}_{1 \mathrm{j}} \ldots \mathrm{x}_{\mathrm{pj}} \text { - independent variables } \\
& \mathrm{a}_{0}, \mathrm{a}_{1}, \ldots \mathrm{a}_{\mathrm{j}} \text { - parameters to be estimated } \\
& \varepsilon_{\mathrm{j}} \text { - error }
\end{aligned}
$$

The data from the test results were downloaded from the OECD website. The independent variables used were: the level of average gross salaries in OECD countries and the number of students per teacher, data available online on the OECD website. The salaries of lower secondary education teachers (ISCED 2) in the education system were taken into account as gross average salaries according to the salary scales in the analysed countries for the period 2017-2018 expressed in USD. The period was chosen due to the last two years possibly being decisive on the PISA test results regarding the quality of teaching.

Separate estimates were made for all three areas tested: math, reading, and science based on the average gross salaries of beginners, 15-year-old teachers, and the top average salaries in the system, as well as the second independent variable student- 
teacher ratio in lower secondary education. In order to be able to compile the regression model, it was necessary to eliminate the countries for which no statistical data were available for any of the variables analysed. Thus, the following countries were eliminated: Australia, Belgium, China, Canada, Saudi Arabia, South Africa, India, Russia. At the same time, after the Grubbs test, Luxembourg was eliminated because the level of average salaries was above the critical value so the data for this country cannot be taken into account in estimating the regression parameters. The parameters of the regression equation can be seen in table no.5

Table 5. Variables, symbols, description, variable type

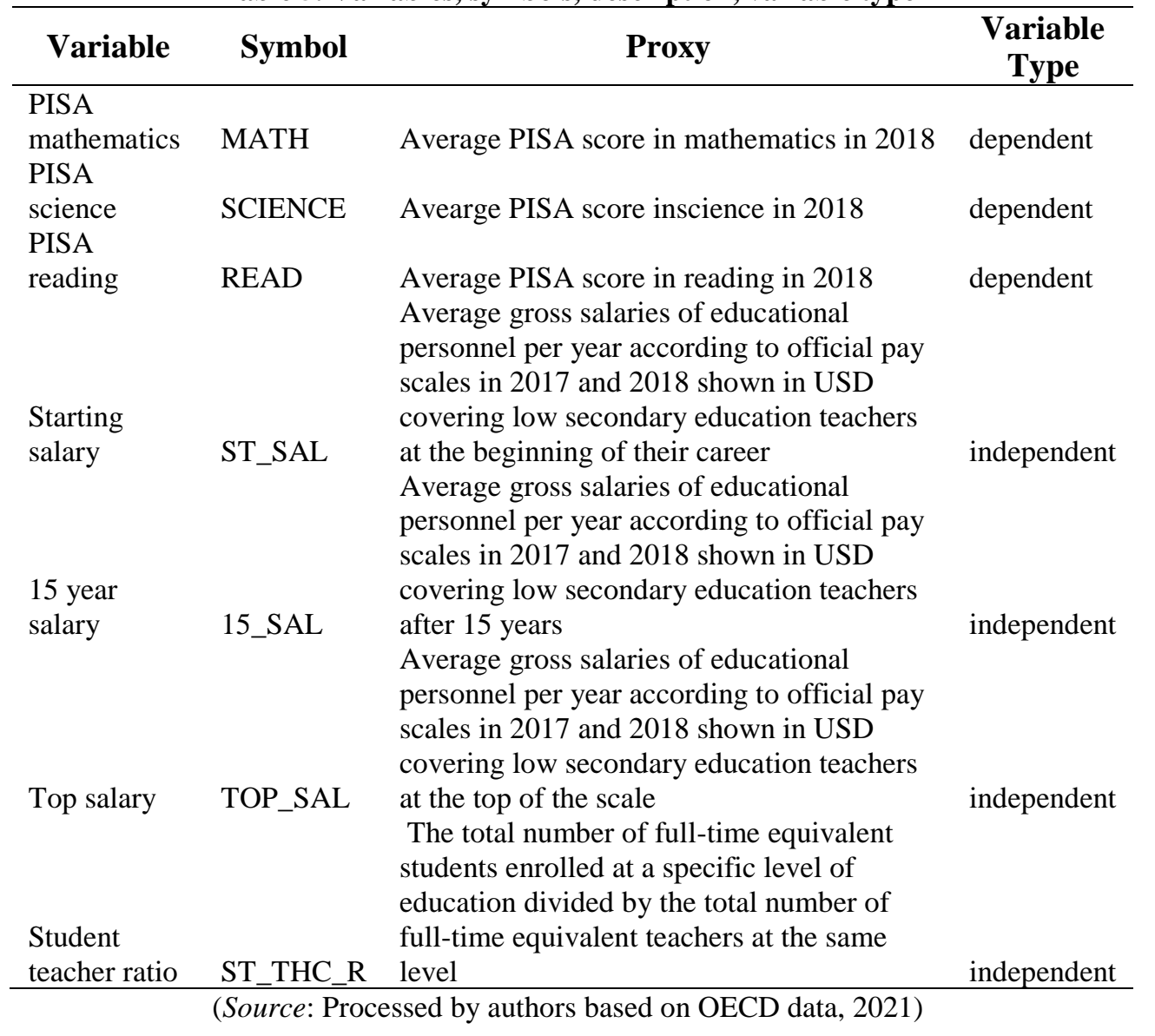

Using the parameters presented, the 9 regression equations were formed:

$\mathrm{MATH}_{\mathrm{it}}=\alpha_{00}+\alpha_{01} * \mathrm{ST}_{-} \mathrm{SAL}_{\mathrm{it}}+\alpha_{02} * \mathrm{ST} \_\mathrm{THC} \mathrm{R}_{\mathrm{it}}+\varepsilon_{\mathrm{it}}$

$\mathrm{MATH}_{\mathrm{it}}=\alpha_{10}+\alpha_{11} * 15 \_\mathrm{SAL} \mathrm{L}_{\mathrm{it}}+\alpha_{12} * \mathrm{ST} \_\mathrm{THC} \_\mathrm{R}_{\mathrm{it}}+\varepsilon_{\mathrm{it}}$

$\mathrm{MATH}_{\mathrm{it}}=\alpha_{20}+\alpha_{21} *$ TOP_SAL ${ }_{\text {it }}+\alpha_{22} * \mathrm{ST}_{-} \mathrm{THC} \mathrm{R}_{\mathrm{it}}+\varepsilon_{\mathrm{it}}$

SCIENCEit $=\beta_{00}+\beta_{01} *$ ST_SALit $+\beta_{02}{ }^{*}$ ST_THC_Rit $+\varepsilon i t$ 
SCIENCEit $=\beta_{10}+\beta_{11} * 15$ SALit $+\beta_{12} *$ ST_THC_Rit $+\varepsilon$ it

SCIENCEit $=\beta_{20}+\beta_{21} *$ TOP SALit $+\beta_{22} *$ ST THC Rit $+\varepsilon$ it

$\operatorname{READ}_{\text {it }}=\gamma_{00}+\gamma_{01} *$ ST_SALit $+\gamma_{02} *$ ST_THC_Rit $+\varepsilon i t$

$\operatorname{READ}_{\mathrm{it}}=\gamma_{10}+\gamma_{10} * 15$ SALit $+\gamma_{12} * \mathrm{ST}$ THC_Rit $+\varepsilon$ it

$\operatorname{READ}_{\mathrm{it}}=\gamma_{20}+\gamma_{21} *$ TOP_SALit $+\gamma_{22} * \overline{\mathrm{ST}}$ _THC_Rit + eit

As it can be seen in the equations presented 2-9, the dependent variables are: the average score obtained by students in a country in mathematics (MATH), science (SCIENCE) and reading (READ). The independent variables are: salaries in the education system at the beginning (ST_SAL), at 15 (15_SAL), and top (TOP_SAL), the number of students per teacher (ST_THC_R), i represents the countries, $t$ represents the year, $\alpha_{00}, \alpha_{10}, \alpha_{20}, \beta_{00}, \beta_{10}, \beta_{20}, \gamma_{00}, \gamma_{10}, \gamma_{20}$ represent the constant coefficient, $\alpha_{01}-\gamma_{22}$ represent the coefficients of the independent variables in each equation and $\varepsilon$ represents the errors.

The tests were performed using Microsoft Excel and EViews student software.

\section{Teachers' salaries student teacher ratio and academic performance - results}

The authors developed multiple regression models for each area of PISA math, reading, and science tests based on beginner salaries, salaries after 15 years of experience, top salaries in lower secondary education and student teacher ratio.

The average salary calculated for the two reference years for all countries and for all three levels, expressed in $\$ 100$, was taken into account for salaries. In the first instance, Scatter plot graphs were made to find out if some linear correlation can be observed between the salary variables and the average scores obtained by students in the PISA tests separately for each field and each salary level as well as between PISA scores and the number of students per teacher The graphs are presented below in graphs no.1-12.

Chart. 1 Mathematics vs starting salaries

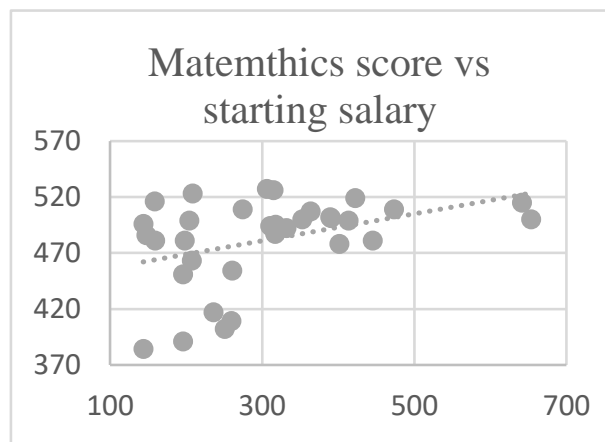

(Source: Authors' Processing, 2021)

\section{Chart 2. Mathematics vs 15 years} salaries

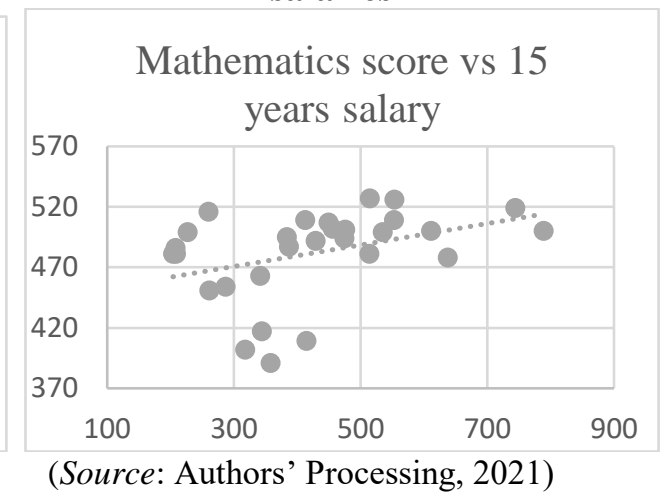




\section{Chart 3. Mathematics vs top salaries}

Mathematics score vs top salary

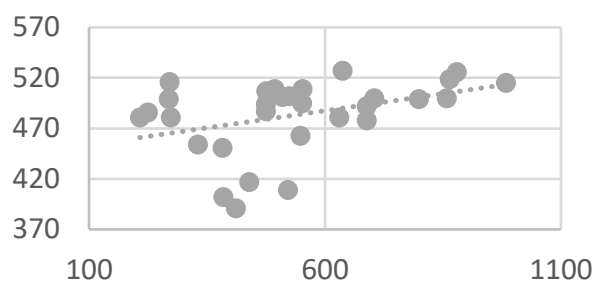

(Source: Authors' Processing, 2021)

Chart 5. Science vs 15-years Salaries

Science vs 15 years salary

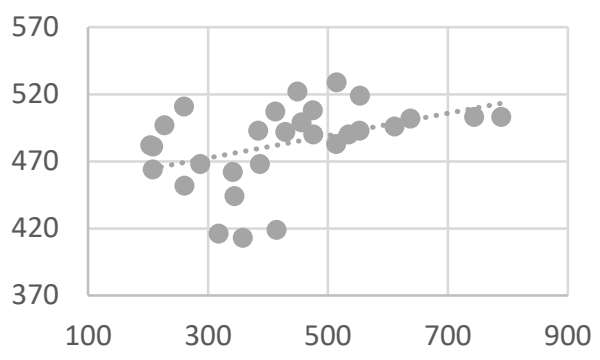

(Source: Authors' Processing, 2021)

Chart 7. Reading vs starting Salaries

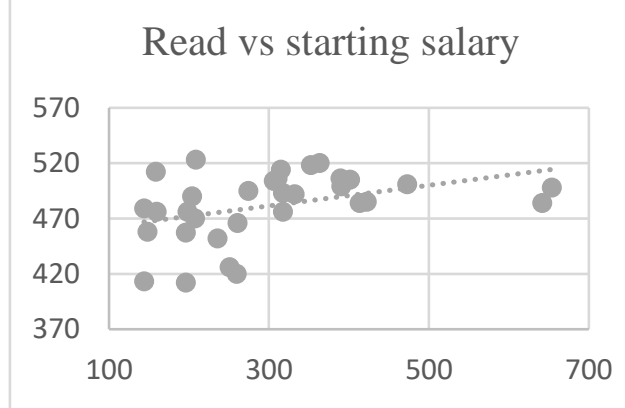

(Source: Authors' Processing, 2021)
Chart 4. Science vs starting salaries

Science vs starting salary

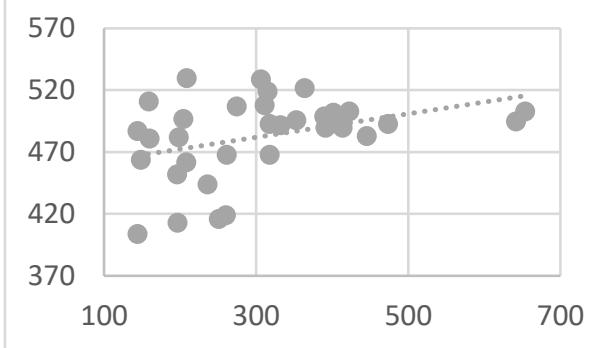

(Source: Authors' Processing, 2021)

Chart 6. Science vs Top Salaries

Science vs top salary

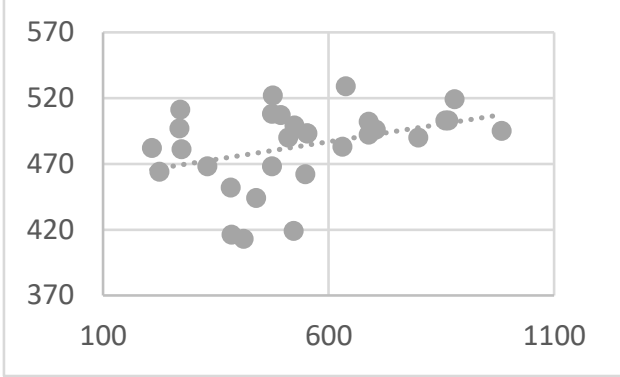

(Source: Authors' Processing, 2021)

Chart 8. Reading vs 15-years Salaries

Read vs 15 years salary

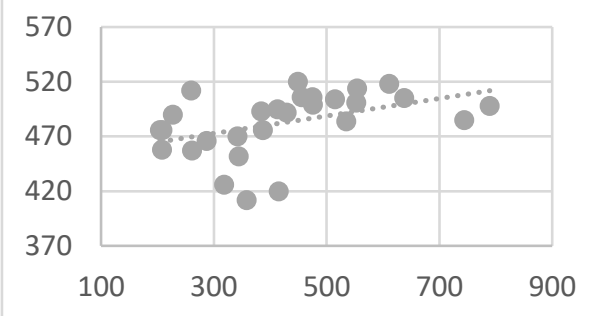

(Source: Authors' Processing, 2021) 


\section{Chart 9. Reading vs Top Salaries}

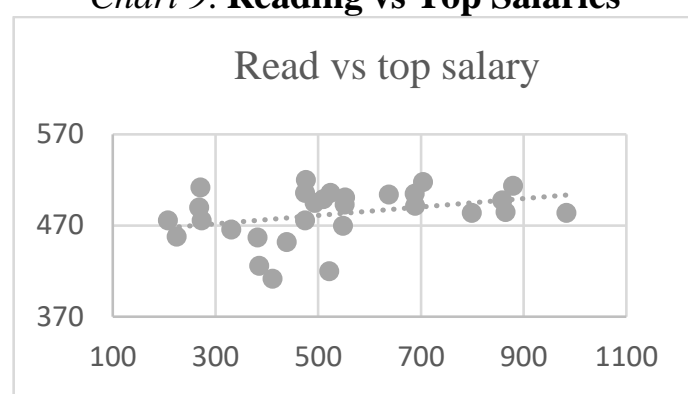

(Source: Authors' Processing, 2021)

As can be seen in graphs 1-9, a linear correlation can be observed between the dependent variable PISA Score and the independent variable average salaries between 2017-2018 with an increasing slope, so the correlation is positive. Graphs 10-12 show the correlations between the test score and the number of students per teacher.

\section{Chart 10. Math vs Student-Teacher} Ratio

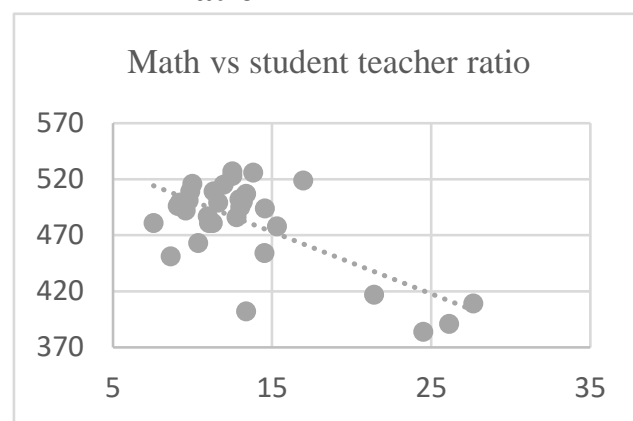

(Source: Authors' Processing, 2021)

\section{Chart 11. Science vs Student-Teacher Ratio}

\section{Science vs student teacher ratio}

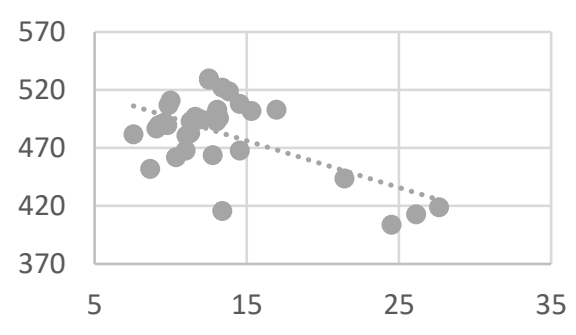

(Source: Authors' Processing, 2021)

Chart 12. Read vs Student-Teacher

Ratio

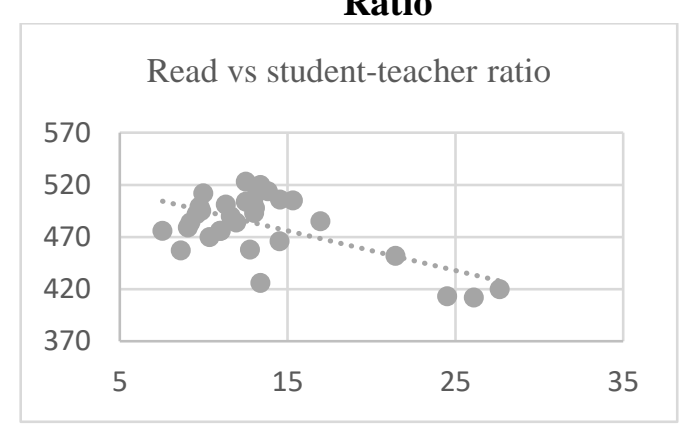

(Source: Authors’ Processing, 2021) 
As it can be seen in the graphs, there is a correlation between the test results and the number of students per teacher, and the slope of the line indicates that the correlation is negative.

The results of the nine regression models and the $\mathrm{F}$ test can be seen in Tables $6 ; 7 ; 8$

Table 6. Values of Regression Statistics and Test $F$ in Math

\begin{tabular}{lccccc}
\hline \multicolumn{1}{c}{$\begin{array}{c}\text { Statistics of PISA } \\
\text { subject }\end{array}$} & $\begin{array}{c}\text { Multiple } \\
\text { R }\end{array}$ & R Square & $\begin{array}{c}\text { Adjusted } \\
\text { R Square }\end{array}$ & $\begin{array}{c}\text { Standard } \\
\text { Error }\end{array}$ & $\begin{array}{c}\text { F Statistic } \\
\text { Value }\end{array}$ \\
\hline $\begin{array}{l}\text { MATH vs ST_SAL \& } \\
\text { ST_THC_R (N =33) }\end{array}$ & 0.7464 & 0.5571 & 0.5276 & 27.15 & $18,87 * * *$ \\
$\begin{array}{l}\text { MATH vs 15_SAL \& } \\
\begin{array}{l}\text { ST_THC_R (N=29) } \\
\text { MATH vs TOP_SAL \& }\end{array}\end{array}$ & 0.7652 & 0.5856 & 0.5537 & 24.4 & $18.37 * * *$ \\
$\begin{array}{l}\text { ST_THC_R (N=30) } \\
\text { * } \mathrm{p}<0.5\end{array}$ & $* * \mathrm{p}<0.01$ & & & & \\
\hline
\end{tabular}

Table 7. Values of Regression Statistics and Test $F$ in Science

\begin{tabular}{lccccc}
\hline \multicolumn{1}{c}{$\begin{array}{c}\text { Statistics of PISA } \\
\text { subject }\end{array}$} & $\begin{array}{c}\text { Multiple } \\
\text { R }\end{array}$ & R Square & $\begin{array}{c}\text { Adjusted } \\
\text { R Square }\end{array}$ & $\begin{array}{c}\text { Standard } \\
\text { Error }\end{array}$ & $\begin{array}{c}\text { F Statistic } \\
\text { Value }\end{array}$ \\
\hline $\begin{array}{l}\text { SCIENCE vs ST_SAL \& } \\
\text { ST_THC_R (N =33) }\end{array}$ & 0.6636 & 0.4404 & 0.4031 & 25,51 & $11,81^{* * * *}$ \\
$\begin{array}{l}\text { SCIENCE vs 15_SAL \& } \\
\text { ST_THC_R (N=29) }\end{array}$ & 0.7152 & 0.5115 & 0.4739 & 22,22 & $13,61 * * *$ \\
$\begin{array}{l}\text { SCIENCE vs TOP_SAL } \\
\text { \& ST_THC_R (N=30) }\end{array}$ & 0.652 & 0.4252 & 0.3826 & 23.72 & $9.98^{* * * *}$ \\
\hline & & & & & \\
\hline
\end{tabular}

Table 8. Values of Regression Statistics and Test $F$ in Reading

\begin{tabular}{|c|c|c|c|c|c|}
\hline $\begin{array}{c}\text { Statistics of PISA } \\
\text { subject }\end{array}$ & $\begin{array}{l}\text { Multiple } \\
\quad \mathbf{R}\end{array}$ & R Square & $\begin{array}{l}\text { Adjusted } \\
\text { R Square }\end{array}$ & $\begin{array}{l}\text { Standard } \\
\text { Error }\end{array}$ & $\begin{array}{l}\text { F Statistic } \\
\text { Value }\end{array}$ \\
\hline $\begin{array}{l}\text { READ vs ST_SAL \& } \\
\text { ST_THC_R }\left(\mathrm{N}=32^{\mathrm{a}}\right)\end{array}$ & 0.6906 & 0.477 & 0.4409 & 22.92 & $13.22 * * *$ \\
\hline $\begin{array}{l}\text { READ vs } 15 \text { SSAL \& } \\
\text { ST_THC_R }\left(\mathrm{N}=28^{\mathrm{a}}\right)\end{array}$ & 0.7557 & 0.5712 & 0.5369 & 19.72 & $16.65^{* * *}$ \\
\hline $\begin{array}{l}\text { READ vs TOP_SAL \& } \\
\text { ST_THC_R }\left(N=29^{a}\right)\end{array}$ & 0.6661 & 0.4438 & 0.401 & 22.02 & $10.37 * * *$ \\
\hline
\end{tabular}

As can be seen from Tables no.6;7;8 the probability of statistical $\mathrm{F}$ is below the significance threshold of $1 \%$ in all fields and at all levels of salaries studied. 
The values of the estimated coefficients for the mathematics field and the values of the $t$ test can be seen in Table 9., for the science field in Table 10., and for the reading field, the results of the estimated coefficients can be seen in Table11.

Table 9. Values of coefficients and t-Statistics in Mathematics

\begin{tabular}{|c|c|c|c|c|c|}
\hline \multicolumn{3}{|c|}{ Coefficient values $\&$ T statistic } & \multirow{2}{*}{$\begin{array}{l}\begin{array}{l}\text { Coefficient } \\
\text { (Intercept) }\end{array} \\
522.28 \\
(19.28)\end{array}$} & \multirow{2}{*}{$\begin{array}{l}\begin{array}{l}\text { Coefficient } \\
\text { (Salaries) }\end{array} \\
\begin{array}{r}0.09 \\
(0.03)\end{array}\end{array}$} & \multirow{2}{*}{$\begin{array}{l}\begin{array}{l}\text { Coefficient } \\
\text { (Student } \\
\text { teacher } \\
\text { ratio) }\end{array} \\
\\
\quad \begin{array}{r}-5.20 \\
(0.99)\end{array}\end{array}$} \\
\hline \multirow{6}{*}{ MATH vs } & \multirow{2}{*}{$\begin{array}{l}\text { ST_SAL\& } \\
\text { ST_THC_R }\end{array}$} & $\begin{array}{c}\text { Coefficient } \\
\text { (standard error) }\end{array}$ & & & \\
\hline & & T statistic & $27.08 * * *$ & $2.55 * *$ & $-5.21 * * *$ \\
\hline & \multirow{2}{*}{$\begin{array}{l}\text { 15_SAL\& } \\
\text { ST_THC_R }\end{array}$} & $\begin{array}{c}\text { Coefficient } \\
\text { (standard error) }\end{array}$ & $\begin{array}{r}505.76 \\
(17.82)\end{array}$ & $\begin{array}{r}0.10 \\
(0.03)\end{array}$ & $\begin{array}{r}-5.26 \\
(0.99)\end{array}$ \\
\hline & & T statistic & $28.37 * * *$ & $3.60 * *$ & $-5.28 * * *$ \\
\hline & \multirow{2}{*}{$\begin{array}{l}\text { TOP_SAL\& } \\
\text { ST_THC_R }\end{array}$} & $\begin{array}{c}\text { Coefficient } \\
\text { (standard error) }\end{array}$ & $\begin{array}{l}510.67 \\
(18.54)\end{array}$ & $\begin{array}{r}0.07 \\
(0.02)\end{array}$ & $\begin{array}{r}-5.01 \\
(1.03)\end{array}$ \\
\hline & & T statistic & $27.53 * * *$ & $3.15 * *$ & $-4.86 * * *$ \\
\hline
\end{tabular}

Table 10. Values of coefficients and t-Statistics on Science

\begin{tabular}{|c|c|c|c|c|c|}
\hline \multicolumn{3}{|c|}{ Coefficient values $\& \mathrm{~T}$ statistic } & \multirow{2}{*}{$\begin{array}{r}\begin{array}{l}\text { Coefficient } \\
\text { (Intercept) }\end{array} \\
\begin{array}{r}509.59 \\
(18.12)\end{array}\end{array}$} & \multirow{2}{*}{$\begin{array}{r}\begin{array}{l}\text { Coefficient } \\
\text { (Salaries) }\end{array} \\
0.07 \\
(0.03)\end{array}$} & \multirow{2}{*}{$\begin{array}{l}\begin{array}{l}\text { Coefficient } \\
\text { (Student } \\
\text { teacher } \\
\text { ratio) }\end{array} \\
\quad \begin{array}{r}-3.76 \\
(0.93)\end{array}\end{array}$} \\
\hline \multirow{6}{*}{$\begin{array}{l}\text { SCIENCE } \\
\text { vs }\end{array}$} & \multirow{2}{*}{$\begin{array}{l}\text { ST_SAL\& } \\
\text { ST_THC_R }\end{array}$} & $\begin{array}{c}\text { Coefficient } \\
\text { (standard error) }\end{array}$ & & & \\
\hline & & T statistic & $28.11^{* * *}$ & $2.18 *$ & $-4.02 * * *$ \\
\hline & \multirow{2}{*}{$\begin{array}{l}\text { 15_SAL\& } \\
\text { ST_THC_R }\end{array}$} & $\begin{array}{c}\text { Coefficient } \\
\text { (standard error) }\end{array}$ & $\begin{array}{l}492.25 \\
(16.23)\end{array}$ & $\begin{array}{r}0.09 \\
(0.02)\end{array}$ & $\begin{array}{r}-3.83 \\
(0.90)\end{array}$ \\
\hline & & T statistic & $30.32 * * *$ & $3.57 * *$ & $-4.22 * * *$ \\
\hline & \multirow{2}{*}{$\begin{array}{l}\text { TOP_SAL\& } \\
\text { ST_THC_R }\end{array}$} & $\begin{array}{c}\text { Coefficient } \\
\text { (standard error) }\end{array}$ & $\begin{array}{r}499.89 \\
(17.30)\end{array}$ & $\begin{array}{r}0.05 \\
(0.02)\end{array}$ & $\begin{array}{r}-3.54 \\
(0.96)\end{array}$ \\
\hline & & T statistic & $28.88 * * *$ & $2.66^{*}$ & $-3.69 * *$ \\
\hline
\end{tabular}


Table 11. Values of coefficients and t-Statistic on Reading

\begin{tabular}{|c|c|c|c|c|c|}
\hline \multicolumn{3}{|c|}{ Coefficient values \&T statistic } & \multirow{2}{*}{$\begin{array}{r}\begin{array}{r}\text { Coefficient } \\
\text { (Intercept) }\end{array} \\
\begin{array}{r}506.51 \\
(16.29)\end{array}\end{array}$} & \multirow{2}{*}{$\begin{array}{l}\begin{array}{l}\text { Coefficient } \\
\text { (Salaries) }\end{array} \\
0.07(0.03)\end{array}$} & \multirow{2}{*}{$\begin{array}{r}\begin{array}{l}\text { Coefficient } \\
\text { (Student } \\
\text { teacher } \\
\text { ratio) }\end{array} \\
\\
\quad-3.57 \\
(0.84)\end{array}$} \\
\hline \multirow{6}{*}{$\begin{array}{l}\text { READ } \\
\text { vs }\end{array}$} & \multirow{2}{*}{$\begin{array}{l}\text { ST_SAL\& } \\
\text { ST_THC_R }\end{array}$} & $\begin{array}{c}\text { Coefficient } \\
\text { (standard error) }\end{array}$ & & & \\
\hline & & T statistic & $31.09 * * *$ & $2.40^{*}$ & $-4.23 * * *$ \\
\hline & \multirow{2}{*}{$\begin{array}{l}\text { 15_SAL\& } \\
\text { ST_THC_R }\end{array}$} & $\begin{array}{c}\text { Coefficient } \\
\text { (standard error) }\end{array}$ & $\begin{array}{r}493.39 \\
(14.41)\end{array}$ & $\begin{array}{r}0.09 \\
(0.02)\end{array}$ & $\begin{array}{r}*_{-} 3.83 \\
(0.80)\end{array}$ \\
\hline & & T statistic & $34.23 * * *$ & $3.90 * *$ & $-4.73 * * *$ \\
\hline & \multirow{2}{*}{$\begin{array}{l}\text { TOP_SAL\& } \\
\text { ST_THC_R }\end{array}$} & $\begin{array}{c}\text { Coefficient } \\
\text { (standard error) }\end{array}$ & $\begin{array}{l}502.75 \\
(16.08)\end{array}$ & $\begin{array}{r}0.04 \\
(0.019)\end{array}$ & $\begin{array}{l}-3.51 \\
(0.89)\end{array}$ \\
\hline & & T statistic & $31.25^{* * *}$ & $2.50 *$ & $-3.91 * *$ \\
\hline
\end{tabular}

As can be seen from the tables 9-11 all the coefficients related to the regression models are valid because the probability of the t-test is below the significance threshold of 5\% (Andrei et al., 2018). In order to be sure that the regression models are valid, the following hypotheses were tested:

- Lack of autocorrelation of errors using the Breusch-Godfrey Serial Correlation LM Test, where the null hypothesis is accepted if Prob. ChiSquare is over 5\% (Andrei et al., 2018);

- Homoschedasticity testing using the White test, because this test can detect heteroschedasticity of unknown shape, the null hypothesis is accepted if Prob. Chi-Square> 5\% (Andrei et al., 2018);

- Testing the normal error distribution using the Jarque-Bera test. The null hypothesis is accepted if Probability> 5\%(Andrei et al., 2018);

- Testing the lack of multicollinearity with Variance Inflation Factors. Centered VIF value <10 is supported(Andrei et al., 2018);

The results of the hypothesis tests can be found in Table 12 . 
Table 12. Residual and coefficients diagnostics values

\begin{tabular}{cccccc}
\hline \multirow{2}{*}{ Regression/ Test } & $\begin{array}{c}\text { Prob. Chi- } \\
\text { Squar (Test } \\
\text { White) }\end{array}$ & $\begin{array}{c}\text { Prob. Chi- } \\
\text { Square } \\
\text { (Test } \\
\text { Breusch- } \\
\text { Godfrey })\end{array}$ & $\begin{array}{c}\text { Prob. (Test } \\
\text { Jarque- } \\
\text { Bera) }\end{array}$ & $\begin{array}{c}\text { Centered } \\
\text { VIF }\end{array}$ \\
\hline \multirow{2}{*}{ MATH } & ST_SAL\& ST_THC_R & 0.58 & 0.98 & 0.56 & 1.01 \\
& 15_SAL\&ST_THC_R & 0.58 & 0.74 & 0.28 & 1.01 \\
& TOP_SAL\&ST_THC_R & 0.46 & 0.93 & 0.21 & 1.00 \\
\hline \multirow{2}{*}{ SCIENCE } & ST_SAL\&ST_THC_R & 0.54 & 0.25 & 0.99 & 1.01 \\
& 15_SAL\&ST_THC_R & 0.41 & 0.42 & 0.83 & 1.01 \\
& TOP_SAL\&ST_THC_R & 0.47 & 0.31 & 0.78 & 1.00 \\
\hline \multirow{2}{*}{ READ } & ST_SAL\& ST_THC_R & 0.75 & 0.19 & 0.91 & 1.01 \\
& 15_SAL\&ST_THC_R & 0.70 & 0.18 & 0.85 & 1.01 \\
& TOP_SAL\&ST_THC_R & 0.68 & 0.14 & 0.83 & 1.00 \\
\hline
\end{tabular}

As it can be seen in Table 12, all of the assumptions regarding the verification models are valid because the Chi-Square probability of the White test, the Breusch-Godfrey test and the Jarque-Bera test is over 5\% and the value of Centered VIF is below 10. These results show that the errors are not autocorrelated, homoscedasticity is present, the error distribution is normal and there is no multicollinearity. Thus, it can be stated with certainty that the models have been defined correctly and that the resulting data can be interpreted economically.

\section{Discussion}

From an analysis of the data obtained before, it can be concluded that the regression models are valid, that they were constructed correctly and the results can be interpreted from an economic point of view. As it can be seen from the graphs 1-9, the slopes are not very steep, which shows that although there is a correlation between variables these correlations are not very strong. As it can be seen from the graphs presented, the correlation between salaries and test results is positive, and the correlation between the number of students and the test score is negative. This means that when the salary is increased, the score obtained in the tests increases, and when the number of students for a teacher increases, the score obtained in the PISA tests 
decreases.

Analysing the value of $\mathrm{R}^{2}$, we can observe a fairly close correlation between the variables studied, so in mathematics we can say the variations of the average score obtained in the PISA tests in 2018 were due to changes in salaries or the number of students per teacher in a percentage of $54-59 \%$. In science this percentage varies between $43-51 \%$ and in reading between $44-57 \%$. This result is probably due to the fact that in mathematics, the teacher's contribution and the time allocated to a student has the greatest importance in learning the subject and implicitly in the results, while in other areas individual study is more accessible to students. In the case of mathematics, the correlation between average salaries and test scores is positive and quite strong, with a determination ratio of $55-59 \%$. The value of the coefficient of salary shows that if there is a salary increase of $\$ 100 /$ year, the test results may increase between 0.07-0.1 points. The coefficient of ST_THC_R being negative shows that the relationship between the average score in mathematics and the number of students per teacher is negative meaning that an increase by a student of this ratio, the average score obtained in the PISA test in mathematics decreases by 5.33-5.06 points. In the field of science in terms of salaries, although the ratio of determination is lower than in mathematics, around $45-50 \%$, however, it can be said that there is a positive correlation so that if salaries increase by $\$ 100 /$ year the expected increase in score at science is $0.05-0.09$ points. If the number of students per teacher increases by one student, the expected score in science decreases by 3,54-3,83 points. Similar to reading with a determination ratio of $44-57 \%$, an increase in salaries by $\$ 100$ / year can influence the PISA test score on reading with an increase of 0.04-0.09 points, and an increase in the number of students with a student per teacher could lead to a decrease in the reading score by $-3,51-3,83$ points. Regarding the hypotheses formulated by the authors, hypotheses $\mathrm{H} 1$ and $\mathrm{H} 2$ are accepted, and the alternative hypothesis is rejected.

\section{Conclusions}

Considering the results of the analysis based on the collected data performing nine multiple regression models with the method of the least squares between the average gross salaries in pre-university education at the lower secondary level between 20172018, the average number of students per teacher between 2014- 2018 and the scores obtained in the PISA tests in 2018 from the OECD countries studied, it can be stated that the authors' hypothesis (that there is a correlation between these indicators) is accepted. This correlation means that the variation of any explanatory variable, the average gross salary and the number of students per teacher, generates a variation in the average score obtained in PISA tests.

The ratio of determination obtained by multiple regression in all fields is around 45$60 \%$, means that a large part of the variations of the score obtained at this is due to 
the two explanatory variables studied. In the field of science and reading, the determination ratio is quite low, meaning that in the case of these subjects there are many other factors that determine the variation of the scores obtained. The coefficients of the two variables show how the explanatory variables influence the results obtained by the students. It can be said that the salary increase positively influences the score obtained by students in the tests, however the very large differences between maximum and minimum are not reflected in the scores obtained, so the question is whether a very large increase is justified or not.

The research results show that increasing the salaries of beginners while maintaining other salaries in order to raise academic performance is not a solution to the problem, because the greatest influence has the salaries of teachers with 15 years of experience. Although the efficiency of learning increases with the reduction of the student-to-teacher ratio, it cannot be greatly reduced because this involves in addition to the increase in salary expenses and the increase in other expenses such as current maintenance or investment expenses. Finding an optimal funding formula to cover the needs of salary expenses at the same time with a sufficiently small number of students per teacher is a great challenge and can draw the lines of new research in this direction. Accepting this point of view, it can be seen that reducing the cost of salaries implies an increase in the number of students per teacher, which results in a decrease in student performance and leads to a different approach to the concept of efficiency and effectiveness in education.

This research provides an overview of a section of the budgeting process in the preuniversity education system. It provides benchmarks for managers and policy makers when evaluating the activity of an educational institution in terms of allocating resources for salary expenditures by showing that extreme cost reduction with human capital is not the optimal solution in this case. This paper is part of an ongoing research project, which shows that the level of funding is directly correlated with student performance (Akiba et al., 2012; Belmonte et al., 2020; Britton \& Propper, 2016; Cebula et al., 2015; Holmlund et al., 2010; Hyman, 2017; Kingdon \& Teal, 2007; Leigh, 2012; Southwick \& Gill, 1997). Thus, it contributes to facilitating decision-making in terms of correlating with a better funding system for education because it represents the future of a country. This research has many limitations. One of them is that it does not take into account other forms of income for teachers, such as bonuses, extra income or others. Another limitation could be that there are many other factors that were not taken into account and that have a very strong effect on students' performance such as family situation, natural psychological factors, environment, etc. However, the authors believe that the results show that none of these explanatory variables can be neglected when deciding the level of funding per student by decision makers and their responsibility in finding the best possible formulas for funding is very high. 


\section{References}

Achim, M.-V. (2015) "The new economy-asking for new education approaches. Eevidence for Romania and other post-communist European countries", Procedia Economics and Finance, vol. 32(15): 1199-1208. https://doi.org/10.1016/s2212-5671(15)01498-7

Agyemang, G. (2010) "Accounting for needs? Formula funding in the UK schools sector", Accounting, Auditing and Accountability Journal, vol. 23(1): 82-110. https://doi.org/10.1108/09513571011010619

Akiba, M., Chiu, Y. L., Shimizu, K., \& Liang, G. (2012) "Teacher salary and national achievement: A cross-national analysis of 30 countries", International Journal of Educational Research, vol. 53: 171-181. https://doi.org/10.1016/ j.ijer.2012.03.007

Andrei, T., Mirica, A., Toma, E. I., Oancea, B., \& Herțeliu, C. (2018) Econometrics Theory and applications in EViews and $R$ (Editura Economica (ed.)).

Anessi-Pessina, E., Barbera, C., Sicilia, M., \& Steccolini, I. (2016) "Public sector budgeting: a European review of accounting and public management journals", Accounting, Auditing and Accountability Journal, vol. 29(3): 491-519. https://doi.org/10.1108/AAAJ-11-2013-1532

Belmonte, A., Bove, V., D'Inverno, G., \& Modica, M. (2020) "School infrastructure spending and educational outcomes: Evidence from the 2012 earthquake in Northern Italy", Economics of Education Review, vol. 75 (February 2019), 101951. https://doi.org/10.1016/j.econedurev.2019.101951

Bracci, E., Humphrey, C., Moll, J., \& Steccolini, I. (2015) "Public sector accounting, accountability and austerity: More than balancing the books?", Accounting, Auditing and Accountability Journal, vol. 28(6): 878-908. https://doi.org/10.1108/AAAJ-06-2015-2090

Britton, J., \& Propper, C. (2016) "Teacher pay and school productivity: Exploiting wage regulation", Journal of Public Economics, vol. 133: 75-89. https://doi.org/10.1016/j.jpubeco.2015.12.004

Broadbent, J., \& Guthrie, J. (1992) "Changes in the public sector: A review of recent "Alternative" accounting research", Accounting, Auditing \& Accountability Journal, vol. 5(2): 3-31 https://doi.org/10.1108/09513579210011835

Cebula, R. J., Mixon, F. G., \& Montez, M. A. (2015) "Teachers' salaries and human capital, and their effects on academic performance: an institution-level analysis of Los Angeles County high schools", Journal of Economics and Finance, vol. 39(2): 347-356. https://doi.org/10.1007/s12197-013-9261-3

Chang, C. F. (1980) "Teachers salaries, production cost of education, and educational expenditures", Journal of Education Finance, vol. 6(2): 226-235. http://www.jstor.org/stable/40703273

Childs, T. S., \& Shakeshaft, C. (1986) "A meta- analysis of research on the relationship between educational expenditures and student Achievement", Journal of Education Finance, vol. 12(2): 249-263. https://www.jstor.org/ 
stable/40703543

Clotfelter, C. T., Glennie, E. J., Ladd, H. F., \& Vigdor, J. L. (2008) "Teacher bonuses and teacher retention in low-performing schools: Evidence from the North Carolina \$1,800 teacher bonus program", Public Finance Review, vol. 36(1): 63-87. https://doi.org/10.1177/1091142106291662

Coleman, J. S. (1969) "Equality of educational opportunity, reexamined", SocioEcon. Plan. Sci., vol. 2: 347-354. https://doi.org/8_1-s2.0-0038012169900299

Edwards, A. C. (1989) "Understanding differences in wages relative to income per capita: The case of teachers' salaries", Economics of Education Review, vol. 8(2): 197-203. https://doi.org/10.1016/0272-7757(89)90007-1

European Comision. (2018) "Teacher's and school head's salaries and allowances in Europe 2016/17", European Commission/EACEA/Eurydice https://eacea.ec. europa.eu/national-policies/eurydice/content/teachers-and-school-headssalaries-and-allowances-europe-201617_en

Ezzamel, M., Robson, K., \& Stapleton, P. (2012) "The logics of budgeting: Theorization and practice variation in the educational field", Accounting, Organizations and Society, vol. 37(5): 281-303. https://doi.org/10.1016/ j.aos.2012.03.005

Feng, L. (2020) "Compensating differentials in teacher labor markets", In The Economics of Education: A Comprehensive Overview (pp. 415-430). Elsevier Ltd. https://doi.org/10.1016/B978-0-12-815391-8.00030-6

Figlio, D. N. (1997) "Teacher salaries and teacher quality", Economics Letters, vol. 55(2): 267-271. https://doi.org/10.1016/S0165-1765(97)00070-0

Giambona, F., \& Porcu, M. (2018) "School size and students' achievement. Empirical evidences from PISA survey data", Socio-Economic Planning Sciences, vol. 64(January): 66-77. https://doi.org/10.1016/j.seps.2017.12.007

Goldhaber, D., Destler, K., \& Player, D. (2010) "Teacher labor markets and the perils of using hedonics to estimate compensating differentials in the public sector", Economics of Education Review, vol. 29(1): 1-17. https://doi.org/ 10.1016/j.econedurev.2009.07.010

Greaves, E., \& Sibieta, L. (2019) "Constrained optimisation? Teacher salaries, school resources and student achievement", Economics of Education Review, vol.73(September):101924. https://doi.org/10.1016/j.econedurev.2019.101924

Hanushek, E. A., \& Rivkin, S. G. (2007) "Pay, working conditions, and teacher quality", Future of Children, vol. 17(1): 69-86. https://doi.org/ 10.1353/foc. 2007.0002

Holmlund, H., McNally, S., \& Viarengo, M. (2010) "Does money matter for schools?", Economics of Education Review, vol. 29(6): 1154-1164. https://doi.org/10.1016/j.econedurev.2010.06.008

Hong, K., \& Zimmer, R. (2016) "Does investing in school capital infrastructure improve student achievement?", Economics of Education Review, vol. 53: 143-158. https://doi.org/10.1016/j.econedurev.2016.05.007

Hoxby, C. M., \& Leigh, A. (2004) "Pulled away or pushed out? Explaining the decline of teacher aptitude in the United States", American Economic Review, 
vol. 94(2): 236-240. https://doi.org/10.1257/0002828041302073

Hyman, J. (2017) "Does money matter in the long run? Effects of school spending on educational attainment", American Economic Journal: Economic Policy, vol. 9(4): 256-280. https://doi.org/10.1257/pol.20150249

Imazeki, J. (2005) "Teacher salaries and teacher attrition", Economics of Education Review, vol.24(4):431-449. https://doi.org/10.1016/j.econedurev.2004.07.014

Jerrim, J., Oliver, M., \& Sims, S. (2019) "The relationship between inquiry-based teaching and students' achievement. New evidence from a longitudinal PISA study in England", Learning and Instruction, vol. 61(January): 35-44. https://doi.org/10.1016/j.learninstruc.2018.12.004

Karakolidis, A., Pitsia, V., \& Emvalotis, A. (2016) "Examining students' achievement in mathematics: A multilevel analysis of the Programme for International Student Assessment (PISA) 2012 data for Greece", International Journal of Educational Research, vol. 79: 106-115. https://doi.org/ 10.1016/j.ijer.2016.05.013

Kelly, J. M. (2003) "The long view: lasting reforms in public budgeting in the 20 century", Journal of Public Budgeting, vol. 15(2): 309-326. https://doi.org/10.1108/JPBAFM-15-02-2003-B007

Kingdon, G. G., \& Teal, F. (2007) "Does performance related pay for teachers improve student performance? Some evidence from India", Economics of Education Review, vol. 26(4):473-486. https://doi.org/10.1016/j.econedurev. 2006.02.007

Kirby, P., Holmes, C. T., Matthews, K. M., Dwight, A., Kirby, P., Holmes, C. T., Matthews, K. M., \& Watt, A. D. (1993) "Factors influencing teacher salaries: An examination of alternative models", Journal of Education Finance, vol. 19(2): 111-121. https://www.jstor.org/stable/40703824

Ladd, H. F. (2007) "Teacher labor markets in developed countries", Future of Children, vol.17(1): 201-217. https://doi.org/10.1353/foc.2007.0006

Landon, J., \& Baird, N. R. (1971) "Monopsony in the market for public school teachers", The American Economic Review, vol. 61(5): 966-971. https://www.jstor.org/stable/1813158

Leigh, A. (2012) "Teacher pay and teacher aptitude", Economics of Education Review, vol.31(3):41-53. https://doi.org/10.1016/j.econedurev.2012.02.001

Lin, T. C. (2010) "Teacher salaries and student achievement: The case of Pennsylvania" Applied Economics Letters, vol. 17(6): 547-550. https://doi.org/10.1080/13504850802167223

Martins, L., \& Veiga, P. (2010) "Do inequalities in parents' education play an important role in PISA students' mathematics achievement test score disparities?", Economics of Education Review, vol. 29(6): 1016-1033. https://doi.org/10.1016/j.econedurev.2010.05.001

Martorell, P., Stange, K. M., \& McFarlin, I. (2016) "Investing in schools: capital spending, facility conditions, and student achievement", Journal of Public Economics, vol.140:13-29. https://doi.org/10.1016/j.jpubeco.2016.05.002

OECD (2014) "National Accounts at a glance", In OECD Publishing (Issue 1). 
OECD Publisher. https://doi.org/10.1057/ukna.2011.3

OECD (2020) Teachers`salaries, student teacher ratio. https://data.oecd.org/ teachers/teachers-salaries.htm

Rivkin, S., Hanushek, E. A., \& Kain, J. F. (2005) "Teachers, schools, and academic achievement", Econometrica, vol. 73(2): 417-458. https://www.jstor.org/ stable/3598793? seq $=1$

Schick, A. (2003) "The role of fiscal rules in budgeting", OECD Journal on Budgeting, vol.3(3):7-34. https://doi.org/10.1787/budget-v3-art14-en

Southwick, L., \& Gill, I. S. (1997) "Unified salary schedule and student SAT scores: Adverse effects of adverse selection in the market for secondary school teachers", Economics of Education Review, vol. 16(2): 143-153. https://doi.org/10.1016/s0272-7757(96)00055-6

Suggate, S. P. (2009) "School entry age and reading achievement in the 2006 Programme for International Student Assessment (PISA)", International Journal of Educational Research, vol. 48(3): 151-161. https://doi.org/ 10.1016/j.ijer.2009.05.001

Taylor, L. L. (2008) "Comparing teacher salaries: Insights from the U.S. census", Economics of Education Review, vol. 27(1): 48-57. https://doi.org/ 10.1016/j.econedurev.2006.06.002

Trinidad, J. E. (2020) "Material resources, school climate, and achievement variations in the Philippines: Insights from PISA 2018", International Journal of Educational Development, vol. 75(January): 102174. https://doi.org/ 10.1016/j.ijedudev.2020.102174

Watlington, E., Shokley, R., Guglielmino, P., \& Felsher, R. (2010) "The high cost of leaving: An analysis of the cost of teacher turnover", University of Illinois Press Stable, vol. 36(1): 22-37. https://www.jstor.org/stable/40704404

Wilson, K., Lambright, K. T., \& Smeeding, T. M. (2004) "School finance, equivalent educational expenditure and income distribution: equal dollars or equal chances for success?", Center for Policy Research, vol. 101. https://doi.org/10.2139/ssrn.1810818 